\title{
Znaczenie kategorii „zaufanie” oraz „ryzyko” dla współczesnej młodzieży
}

KEYWORDS

trust, risk, youth, modernity

\begin{abstract}
Paulina Peret-Drążewska, Znaczenie kategorii "zaufanie” oraz "ryzyko" dla współczesnej młodzieży [The importance of the categories trust and risk for contemporary youth]. Kultura - Społeczeństwo - Edukacja nr 1(19) 2021, Poznań 2021, pp. 7-17, Adam Mickiewicz University Press. ISSN 2300-0422. DOI 10.14746/kse.2021.19.1

This article presents theoretical considerations on the category of trust and risk as constructs particularly important for an individual participating in contemporary socio-cultural realities, especially for young people. Theoretical analyses of the concepts of trust and risk are presented. The basis for these analyses was the concept of the sense of ontological security set in the context of contemporary socio-cultural conditions and globalization processes. Trust and risk are categories of particular importance to young people at present, which is why this age group was emphasized in the theoretical analyses undertaken.
\end{abstract}

\section{Wprowadzenie}

Procesy globalizacji społeczno-kulturowej wymagają rozpatrywania ich przez pryzmat kategorii zmiany rozumianej jako brak stabilizacji, konieczność ciągłego dostosowywania się do wymogów rozpędzonego świata, mobilność i gotowość do podejmowania nowych wyzwań. Konieczność permanentnej, wymuszonej zmiany niesie ze sobą niepewność, brak stałego odniesienia, co skutkuje lękiem

\footnotetext{
* ORCID: https://orcid.org/0000-0002-9228-4009.
} 
i bezradnością wobec wyzwań ponowoczesności. Zaistniała współcześnie otwartość na zmianę prowadzi do zaniku rutyny, przewidywalności i powtarzalności. Odzwierciedla się to w jakości relacji międzyludzkich oraz relacji ja - świat. Hanna Mamzer mówi, iż „współczesna cywilizacja oparta na wartościach zachodnioeuropejskich staje się cywilizacją opartą na zmianie i zmianę gloryfikującą" (Mamzer, 2008: 166). „Koncepcja uczestniczenia w zmianie, doświadczania jej i, co więcej, inicjowania zmiany, zwłaszcza w ramach swojego własnego sposobu funkcjonowania w rzeczywistości wydawała się niezwykle atrakcyjna. Coraz wyraźniej jednak widać, że ze zmiennością życia sobie nie radzimy w całkowicie idealny sposób i zaczynamy poszukiwać ontologicznej pewności, bezpieczeństwa i wiary w to, że pewne wartości będą wartościami niezachwianymi. Zmiana nie jest już tak jednostronnie pozytywnie określana i definiowana” (Mamzer, 2008: 166-167) - konstatuje autorka. Kategoria zmiany, będąca podstawą wszelkich trendów płynnej nowoczesności, jawi się zatem jako wyzwanie dla partycypacji w zaistniałych warunkach społeczno-kulturowych.

To, w jakim stopniu ryzyko, niepokój i niepewność staną się istotne dla funkcjonowania jednostki, zależne jest od wymiaru podstawowego zaufania, jak również ufności wobec świata. Ta kategoria stanowiąca niejako bazę do całożyciowego nastawienia wobec lęków i niepokojów tożsamościowych oraz egzystencjalnych kształtuje się we wczesnym dzieciństwie poprzez jakość relacji ja - opiekun w kontekście sytuacji nieobecności opiekuna. Chodzi tu o wiarę dziecka w to, że osoba nim się opiekująca powróci, pomimo jej aktualnej absencji. Szczególne znaczenie w procesie kształtowania podstawowego zaufania ma również nawyk i rutyna, które sprawiają, że świat staje się bardziej przewidywalny. Podstawowe zaufanie zostało przez Anthony’ego Giddensa określone mianem „emocjonalnej szczepionki przeciw niepokojom egzystencjalnym, które chroni przez zagrożeniami i niebezpieczeństwami, jakie mogą nadejść, i pozwala zachować nadzieję w obliczu wszelkich niesprzyjających okoliczności, z jakimi może się spotkać jednostka" (Mamzer, 2008: 63). Jednostka poprzez podstawowe zaufanie musi wykształcić „kokon ochronny”, aby móc egzystować w świecie chaosu i lęku. Kokon ochronny w ujęciu Giddensa rozumiany jest jako „branie w nawias wydarzeń, które mogłyby stanowić zagrożenie dla cielesnej lub psychicznej integralności jednostki” (Mamzer, 2008: 63-64).

Przedstawiona płynnonowoczesna retoryka określająca istotność kategorii ufności wobec świata jest szczególnie obecna w dyskursie nad współczesną młodzieżą. Relacje jednostki z partycypowaną rzeczywistością społeczno-kulturową intensyfikują się w okresie adolescencji, kiedy to młodzież świadomie podejmuje refleksje nad swoim miejscem w systemie społecznym w ramach realizacji szeregu 
tożsamościowych zadań rozwojowych. Głos młodego pokolenia stanowić może prognostyk przyszłych kierunków rozwoju współczesnych zjawisk socjokulturowych. Zatem kategorie: „zaufanie” oraz „ryzyko” są szczególnie istotne z wielu, wskazanych tu względów, dlatego też niniejszej problematyce poświęcone zostały refleksje teoretyczne stanowiące główną oś narracji i zasadniczy cel niniejszego artykułu ${ }^{1}$.

\section{„Zaufanie" / "ryzyko". Ujęcie teoretyczne}

Jednostka partycypująca w społeczno-kulturowym wymiarze ponowoczesnego świata permanentnej zmiany musi zmierzyć się z nieustannym procesem relatywizacji wartości, zasad oraz idei, które aktualnie przybierają postać „płynnego” elementu autokreacji. Uległy rozproszeniu trwałe elementy rzeczywistości, które stanowiły pewny punkt odniesienia, dający poczucie bezpieczeństwa, co skutkuje niepewnością wobec siebie, innych i świata. Jednakże jednostki poszukują możliwości osiągnięcia poczucia bezpieczeństwa pomimo niespełnionego warunku przewidywalności świata.

Fundamentem, na którym opiera się poczucie bezpieczeństwa, stanowi kategoria „zaufania”. Mówiąc słowami Hanny Mamzer i Tomasza Zalasińskiego, istotność dyskursu „zaufania” wynika z faktu, iż „zmienność świata, zmienność jego aktorów, niepewność dokonywanych predykcji i ocen, powoduje jednak, że zaufanie staje się zjawiskiem kluczowym we współczesnym świecie (...) Zaufanie do siebie i do innych staje się zatem kluczową bazą, która pozwala ludziom funkcjonować w świecie gloryfikującym zmienność” (Mamzer, Zalasiński, 2008: 11). Taki sam pogląd głosi Piotr Sztompka, określając zaufanie jako „ protezę niezbędną do działania w sytuacji niepewności i ryzyka, albo jeszcze inaczej - pomost zbudowany ku innym ponad morzem chaosu i wątpliwości” (Mamzer, Zalasiński, 2008: 24). Wypowiedzi te ukazują istotność zagadnień dotyczących zaufania w kontekście osiągania poczucia bezpieczeństwa ontologicznego.

Zasadność analizy kategorii „Zaufanie” w kontekście poczucia bezpieczeństwa ontologicznego wynika z tezy mówiącej, iż „zmienność świata, która uniemożliwia uzyskanie wiedzy pewnej, niejako w sposób automatyczny wymusza podkreślenie roli «zaufania» jako podłoża, umożliwiającego podejmowanie jakichkolwiek relacji międzyludzkich (...). Ono bowiem (zaufanie) uzasadnia zawieszenie wszelkiego

${ }^{1}$ Zaprezentowane w niniejszym artykule rozważania rozstały poddane szczegółowym analizom w: P. Peret-Drążewska (2014), Wspótczesna młodzież postrzegana z perspektywy rówieśników. Studium teoretyczno-empiryczne, Poznań. 
rodzaju lęków, niepokojów, podejrzliwości i niepewności” (Mamzer, Zalasiński, 2008: 31-32).

Sztompka, podejmując refleksję nad rolą zaufania w warunkach ponowoczesności, wskazuje na wiele istotnych cech, które zostaną dalej przedstawione (Sztompka, 2007, 45-49). Autor podkreślił istotność podmiotowości ludzkich działań, poczucia aktywnego i świadomego tworzenia własnej historii życia. Taki stan wzmacnia orientację na przyszłość, co prowadzi do konieczności odwoływania się do kategorii zaufania. Kolejną cechą ponowoczesnej rzeczywistości, nadającą szczególne znaczenie zaufaniu, stanowi współzależność wielu elementów życia społecznego, tworząca swoistą sieć powiązanych nacisków na jednostkę w kwestii jej społecznego funkcjonowania. Niesie to za sobą umocnienie sytuacji niepewności i nieprzewidywalności, co zwiększa potrzebę odwoływania się do kategorii zaufania. Następną kwestią podkreślającą rolę zaufania we współczesnym świecie jest egzystencja wśród licznych zagrożeń i niebezpieczeństw, które stanowią już niejako stały element rzeczywistości społecznej, z którą należy się nieustannie zmagać. Ponowoczesność oferuje szeroki wachlarz możliwości wyboru różnorodnych sposobów działania. W obliczu mnogości ofert jednostka zatraca pewność, co do słuszności podejmowanych decyzji, a zatem musi odwołać się do zaufania. Współczesna rzeczywistość społeczno-kulturowa cechuje się „nieprzejrzystością”, czyli koniecznością podejmowania działań w sytuacji braku przewidywań, co do efektów owych przedsięwzięć. „Nieprzejrzystymi” są również osoby wokół nas nie mamy możliwości kontroli ich zachowań. W obliczu nieprzewidywalności $\mathrm{w}$ innych możemy jedynie pokładać zaufanie.

Współczesny dyskurs nad kategorią zaufania przenosi jej sposób interpretacji z poziomu jednostkowego (zaufanie jako cecha osobowości podmiotu) na wymiar zależności międzyludzkich $\mathrm{w}$ przestrzeni społeczno-kulturowej. Zatem zaufanie ujmowane jako cecha relacji międzyludzkich wpływa na kształt aktualnej rzeczywistości społecznej. Odnosi się do sposobu interpretacji zamierzeń partnera interakcji. Takie ujęcie jest często prezentowane w koncepcjach socjologii zaufania. Kluczową kwestią jest poszukiwanie odpowiedzi na pytanie o rodzaj owych zamierzeń. Bronisław Misztal w definicji zaufania nie precyzuje kwestii tegoż oczekiwania wobec osoby, którą mamy obdarzyć zaufaniem. „Ufać, to znaczy wierzyć, że rezultaty czyichś zamierzonych działań będą właściwe z naszego punktu widzenia" (Misztal, za: Sztompka, 2007: 70) - wyjaśnia Misztal.

Sztompka, na podstawie szerokiej analizy podejmowanego zagadnienia, definiuje zaufanie jako: „zakład, że niepewne przyszłe działania innych ludzi lub funkcjonowanie urządzeń czy instytucji - będą dla nas korzystne" (Sztompka, 2007: 99). Autor podkreśla, że zaufanie składa się z przekonania, za którym następują okre- 
ślone działania. A zatem zaufanie niesie ze sobą „ryzyko”, ponieważ konsekwencje podjętych aktywności są nieprzewidywalne, szczególnie w czasach permanentnej zmiany. Jednakże należy uwzględnić opozycyjną tezę mówiącą, iż zaufanie oznacza „pominięcie, wzięcie w nawias ryzyka (...) działanie, jakby ryzyko nie istniało. A działać musimy, więc ryzyka uniknąć się nie da” (Sztompka, 2007: 83). Owa sprzeczność stanowi podstawową myśl socjologii zaufania. W ujęciu Sztompki wyznacznikiem zaufania są oczekiwania względem partnera interakcji. Autor wyróżnia oczekiwania efektywnościowe, czyli dotyczące przewidywalnych, racjonalnych i efektywnych działań; oczekiwania aksjologiczne odnoszące się do uczciwości działań; oczekiwania opiekuńcze dotyczące kategorii bezinteresowności i działań altruistycznych.

Jak już zostało zasygnalizowane, współczesny dyskurs nad zaufaniem cechuje się jego wielowymiarowym ujęciem. Akcentuje to Sztompka, dokonując podziału owej kategorii na trzy wymiary, które powinny być ujmowane łącznie, tworząc trójwymiarowy status zaufania (Sztompka, 2007: 134-157). Pierwszym elementem tego złożonego systemu jest zaufanie rozumiane jako relacja - wymiana mogąca przybrać charakter bezpośredni bądź pośredni. Autor wyjaśnia, iż „wymiana ma charakter bezpośredni, kiedy akt obdarzania kogoś zaufaniem wywołuje reakcje wzajemności, to znaczy skutkuje zwróceniem powierzonego obiektu lub rewanżem w postaci odwzajemnienie zaufania (...) Może jednak występować wymiana o charakterze pośrednim, kiedy zaufanie jest istniejącą wyłącznie w naszym umyśle czy w naszej wyobraźni postawą wobec innych, których działania są dla nas ważne. Osoby te czy instytucje nie są świadome zaufania, jakim je obdarzamy, a po prostu działając rutynowo w sposób zgodny z naszymi oczekiwaniami, zaspokajają nasze potrzeby albo realizują nasze cele" (Sztompka, 2007: 135). Kolejny wymiar stanowi zaufanie jako tendencja osobowościowa. W tym ujęciu zaufanie to cecha, specyficzna skłonność osobowościowa osoby, która obdarza zaufaniem innych z zasady, a nie na podstawie racjonalnych przesłanek. U źródeł takiej postawy jest pierwotna socjalizacja, która utrwaliła skłonność do ufania pozostałym członkom społeczności. Owa skłonność została określona przez Sztompkę jako „impuls zaufania” (Sztompka, 2007: 142). Trzeci wymiar zaufania stanowi reguła kulturowa. W tym ujęciu ufność jest bądź normą, bądź też odstępstwem od normy, które wynikają z przyjętych zasad społecznych w danym kontekście kulturowym oraz nacisku społecznego.

Zaufanie traktowane jako reguła społeczna wpływa na kształt kultury w odniesieniu do postawy ufności, co przejawia się uogólnionym ufnym bądź nieufnym nastawieniem wobec innych w makroskali. Jeśli występuje ogólna tendencja do obdarzania innych zaufaniem, mówimy o kulturze zaufania, czyli „rozpowszech- 
nionych w społeczeństwie regułach, które nakazują traktować zaufanie i wiarygodność jako wartości, a ufność wobec innych i wywiązywanie się ze zobowiązań jako normy właściwego postępowania” (Sztompka, 2007: 300). Z kolei kultury promujące "nieufność, podejrzliwość i ostrożność oparte na przekonaniu, że nikt nie jest godny zaufania" (Sztompka, 2007: 300) określane są mianem kultury nieufności i cynizmu. Aktualnie w wielu krajach na całym świecie, także w Polsce, występuje przesunięcie w stronę kultury niskiego zaufania, co przejawia się społeczną atmosferą nieufności, podejrzliwości, niepokojów i lęków. Zaistniała sytuacja jest rezultatem postępujących procesów globalizacyjnych, które niosą ze sobą rozpad wspólnotowości, chaos reguł moralnych, postępującą urbanizację, osłabienie instynktu samoorganizacji. A zatem, jak wskazuje Sztompka, „proces globalizacji podważa lub osłabia wszystkie czynniki sprzyjające wytwarzaniu się silnego i rozpowszechnionego zaufania społecznego: utrudnia kalkulację, ocenę wiarygodności osób, ról społecznych, organizacji i instytucji oraz przeszkadza wytwarzaniu się klimatu zaufania, kultury zaufania" (Sztompka, 2007: 182). Jednakże z drugiej strony globalizacja prowadzi do rozwoju kultury zaufania w wymiarze globalnym, co autor rozumie jako rozkwit globalnej wspólnotowości, która „wiązałaby - ponad podziałami rasowymi, etnicznymi, narodowymi, państwowymi, klasowymi, zawodowymi - wszystkich porządnych ludzi, gotowych do kooperacji, tolerancyjnych, rezygnujących z przemocy, wiarygodnych, wywiązujących się ze zobowiązań, darzących innych szacunkiem i zaufaniem" (Sztompka, 2007: 397-398).

Zaufanie w wymiarze makrospołecznym leży u podstaw rozważań Francisa Fukuyamy, który ujmuje tę kategorię jako podstawę kapitału społecznego. Według jego koncepcji „zaufanie to mechanizm oparty na założeniu, że innych członków danej społeczności cechuje uczciwe i kooperatywne zachowanie oparte na wspólnie wyznawanych normach" (Fukuyama, 1997: 38). Podzielanie wspólnie wyznawanych norm oraz prymat interesów grupowych nad indywidualnymi to podstawa kategorii zaufania, która przekłada się na korzyści ekonomiczne. Wartość zaufania uznawana wśród członków społeczeństwa powoduje otwartość na innych, częste nawiązywanie relacji interpersonalnych, co pomnaża kapitał społeczny rozumiany jako „zdolność wynikająca z rozpowszechnienia zaufania w obrębie społeczeństwa lub jego części” (Fukuyama, 1997: 39). Podobny pogląd przedstawił Robert Putnam, mówiąc, iż „kapitał społeczny to takie cechy organizacji społeczeństwa, jak zaufanie, normy i powiązania, które mogą zwiększyć sprawność społeczeństwa, ułatwiając skoordynowane działania" (Putnam, 1995: 258). Definicja tego pojęcia mówi o korzyściach jednostkowych wynikających z aktywnej, ufnej postawy szerszej grupy społecznej. Jak wskazuje Hanna Mamzer: „uczestniczenie w interakcjach społecznych, które umożliwiają ufanie, sprzyja bardziej spontanicznym, 
otwartym i żywiołowym zachowaniom, umożliwia też pełniejsze zaangażowanie $\mathrm{w}$ relacje społeczne. Jest to o tyle istotne, że przekłada się nie tylko na prywatnie utrzymywane relacje o charakterze interpersonalnym, ale także na relacje w stosunku do całej społeczności” (Mamzer, Zalasiński, 2008: 41). A zatem podstawę kapitału społecznego tworzą indywidualne kompetencje interpersonalne członków społeczeństwa. W dobie spadku poziomu zaufania obserwuje się zupełnie odwrotne tendencje, mianowicie „wyraźny wzrost przestępczości i przemocy, rozpad struktury rodziny, upadek wielu pośrednich instytucji społecznych czy wreszcie wyraźnie odczuwany wśród Amerykanów brak wspólnych wartości i poczucia więzi społecznej z otoczeniem” - pisze Fukuyama (Fukuyama, 1997: 21). Sądzę, że taki stan społeczny dotyczy wszystkich krajów wysokorozwiniętych, w których procesy globalizacyjne kształtują relacje międzyludzkie.

W ujęciu Giddensa kategoria zaufania ma bezpośredni wpływ na uzyskanie poczucia bezpieczeństwa. W celu osiągnięcia tego stanu jednostki ponowoczesności stosują różnego rodzaju strategie. Jedną z nich jest brak refleksji nad pytaniami egzystencjalnymi, co autor tłumaczy jako „wzięcie w nawias pytań o nas samych, o innych i o świat rzeczy, w którego istnienie nie można wątpić, aby skutecznie działać” (Giddens, 2010: 52). Brak pytań egzystencjalnych sprawia, że ulega redukcji lęk egzystencjalny, ponieważ „żeby żyć, przyjmujemy za oczywiste kwestie, które w świetle wielowiekowych dociekań filozoficznych - rozsypują się w pył pod sceptycznym spojrzeniem. Należą do nich, trafnie tak określane, kwestie egzystencjalne (...). Są to kwestie czasu, przestrzeni, ciągłości i tożsamości” (Giddens, 2010: 53). Swoistej „niewypowiedzianej” (w sensie - nie wyzwalającej konieczności refleksji, lecz danej wprost) odpowiedzi na pytania egzystencjalne daje podstawowe zaufanie nabyte we wczesnym dzieciństwie. Kategoria ta jest zarazem źródłem poczucia bezpieczeństwa ontologicznego w ujęciu Giddensa. „Ufność pokładana w egzystencjalnych punktach zaczepienia, w sensie emocjonalnym i w pewnym stopniu poznawczym, opiera się na nabytej we wczesnych doświadczeniach dziecka pewności co do tego, że na innych można polegać (...) Wykształcone dzięki trosce pierwszych opiekunów podstawowe zaufanie w krytyczny sposób wiąże tożsamość jednostki z ocenami innych" (Giddens, 2010: 54).

Kategoria zaufania zawsze w swoich ramach zawiera pierwiastek ryzyka, ponieważ ufność pokładana jest w stosunku do jego braku. A zatem „zaufanie” i „ryzyko" to kategorie podlegające ścisłej wzajemnej korelacji.

Pojęcie ryzyka funkcjonuje powszechnie w języku potocznym. Ujmowane jest wówczas jako „zagrożenie, niebezpieczeństwo, prawdopodobieństwo niepowodzenia i niekorzystnych skutków, jakie wyzwala podjęcie przez nas pewnych działań” (Sztompka, 2007: 100) - wyjaśnia Sztompka. Odmienne jest natomiast 
traktowanie ryzyka w kontekście zaufania. Wówczas oznacza ono „prawdopodobieństwo, że nasze oczekiwania wyrażone $\mathrm{w}$ akcie zaufania nie zostaną spełnione" (Sztompka, 2007: 100). Sztompka zauważył wiele wspólnych cech określających zarazem ryzyko, jak i zaufanie. Przede wszystkim obie kategorie odnoszą się do orientacji na przyszłość oraz związane są z „podmiotowym zaangażowaniem jednostki” (Sztompka, 2007: 81-82) - co wynika z faktu, iż stopień ryzyka wynika $z$ indywidualnych wyborów, decyzji i działań jednostki, która stanowi sama o sobie.

Kategoria ryzyka stała się wyznacznikiem czasów późnej nowoczesności, co określone zostało mianem „społeczeństwa ryzyka” (U. Beck). W tym kontekście ryzyko oznacza globalne niebezpieczeństwa i zagrożenia wynikające ze specyfiki ponowoczesności. Podobne stanowisko wobec zagadnienia ryzyka zajął Giddens, którego zdaniem „pojęcie ryzyka nabiera szczególnego znaczenia w społeczeństwie, które zrywa z przeszłością i tradycyjnymi sposobami działania i staje wobec tyleż otwartej, co wątpliwej przyszłości” (Giddens: 53). Mając na uwadze charakter zastanej teraźniejszości, gdzie dominuje prymat zmiany, należałoby przekształcić sposób rozumienia kategorii ryzyka, co proponuje Hanna Mamzer. Autorka uważa, że „ryzyko powiązane jest z poczuciem niepewności wynikającej z fragmentacji rzeczywistości i jej płynności, niemożności jej ogarnięcia i poznawczego opanowania (...) Ryzyko pojmowane jest jako niepewność i wzrastające poczucie braku kontroli nad światem, który nieustannie się zmienia i będzie się zmieniać" (Mamzer, 2008: 190).

Opisane kategorie „zaufanie” oraz „ryzyko” stanowią fundament rozważań nad pojęciem poczucia bezpieczeństwa ontologicznego. To zagadnienie usytuowane jest na pograniczu wielu dziedzin nauk z uwagi na wielość kontekstów oraz aspektów je określających. Interdyscyplinarność pojęcia poczucia bezpieczeństwa ontologicznego wymaga rozpatrywania jego istotności przez pryzmat różnorodnych dyscyplin naukowych. Wielokrotnie trudna do określenia jest geneza danej koncepcji i przyporządkowanie jej do konkretnej dziedziny nauk ze względu na przenikanie wielu nurtów pochodzących z wielu źródeł naukowych, tworzących łącznie daną, eklektyczną koncepcję.

Z opozycji zaufanie a ryzyko wynika kolejny dylemat człowieka w świecie permanentnej zmiany, mianowicie chęć osiągnięcia poczucia bezpieczeństwa ontologicznego a jego utrata ze względu na charakter zastanych warunków społeczno-kulturowych. Powszechnie wskazuje się na transfer podmiotowo zlokalizowanego poczucia bezpieczeństwa na wspólnotowy, społeczny obszar funkcjonowania człowieka, co prowadzi do połączenia socjologicznego oraz psychologicznego ujęcia poczucia bezpieczeństwa. Pierwszych analiz kategorii poczucia bezpieczeństwa 
dokonał w latach 60. XX wieku Giddens, reprezentujący socjologiczny status refleksji nad owym zagadnieniem, wykorzystując koncepcję podstawowej ufności Erika H. Eriksona, należącą do pola zainteresowań psychologii. W ujęciu Giddensa poczucie bezpieczeństwa ontologicznego to „poczucie trwania i porządku zdarzeń, w tym zdarzeń wykraczających poza obszar bezpośredniego doświadczania jednostki” (Giddens, 2010: 314).

\section{„Zaufanie” / „ryzyko" a współczesna młodzież}

Grupą społeczną, która szczególnie „uwikłana” jest w warunki permanentnej zmiany, a co za tym idzie - związana jest istotnie z kategoriami „zaufanie” oraz „ryzyko” - stanowi młodzież. Młodzi muszą zmierzyć się z szeregiem zmian wynikających $\mathrm{z}$ ich wewnętrznego stanu psychospołecznego realizacji zadań rozwojowych na drodze od dzieciństwa do dorosłości, jak również egzystując we współczesności, są aktywnymi podmiotami, których dotyczy konieczność dostosowania się do szeregu zmian z tejże egzystencji wynikających. Zatem młodzież jest niejako w podwójnej sytuacji „bycia pomiędzy” - tej zewnętrznej i wewnętrznej przestrzeni partycypacji w świecie.

Młodzież partycypująca w płynnonowoczesnej rzeczywistości opartej na zmianie, stojąca w obliczu konieczności realizacji zadań rozwojowych adolescencji, borykająca się z trudnościami wynikającymi z „bycia pomiędzy” dzieciństwem a dorosłością oraz „pomiędzy” sprzecznymi tendencjami tkwiącymi wewnątrz jednostki zagubionej w gąszczu licznych powinności, wnosi istotny wkład w ocenę jakości zachodzących procesów społeczno-kulturowych, bowiem niejako jest zarazem twórcą, jak też odbiorcą tych zmian. $Z$ uwagi na to warto podjąć refleksję na temat sytuacji „współczesnych młodych”, których czasem niezauważalny głos stanowi fundamentalną część dyskursu nad ich partycypacją w zaistniałych warunkach społeczno-kulturowych. Szczególne miejsce w tego typu analizach powinny mieć kategorie zaufania oraz ryzyka, bowiem nie pozostają one bez znaczenia dla partycypacji młodych w życiu społecznym oraz ich jednostkowych losów w dalszym dorosłym funkcjonowaniu we współczesnej rzeczywistości socjokulturowej.

Adolescenci chcą mieć możliwość oddziaływania na otaczający świat, chcą kreować rzeczywistość społeczno-kulturową, w której egzystują. Młodzież nie tylko chce mieć sprawczą moc działania, ale wręcz powinna przejmować inicjatywę w kreacji przestrzeni społeczno-kulturowej. Idąc dalej, osoby młode poprzez swoją specyfikę funkcjonowania tak też czynią, stając się motorem rozwoju społeczeństw. Do tego typu działań niezbędne jest określenie poziomu zaufania oraz 
ryzyka, bowiem to te kategorie są czynnikami powiązanymi z rozwojem jednostkowym młodych, jak też rozwojem społeczeństw w makroskali.

Współczesna młodzież, która doskonale rozumie realia współczesności, elastycznie się do nich dostosowuje i jednocześnie je kreuje. Pokolenia współczesnej młodzieży, mając świadomość egzystencji w społeczeństwie ryzyka, przejawiają dwie tendencje - fascynację ryzykiem oraz obawą przed ryzykiem.

Grupa młodzieży odmiennie od dorosłych ujmuje kategorie zaufania oraz ryzyka ze względu na specyfikę etapu rozwojowego adolescencji, którego głównym zadaniem rozwojowym jest kształtowanie tożsamości, do czego niezbędnym czynnikiem jest eksploracja rzeczywistości czy poszukiwanie wrażeń.

Ryzyko stanowi jeden z elementów stylu życia współczesnej młodzieży - jak ujmuje to Zbyszko Melosik, opisując współczesność w kategorii kultury skoku adrenaliny i ryzyka, której podstawowym założeniem jest „maksymalizacja wrażeń” poprzez podejmowanie ryzyka $\mathrm{w}$ przejawianiu niebezpiecznych i ekstremalnych zachowań (Melosik, 2001: 34-36).

Podejmowanie ryzyka to nieodłączny element stylu(ów) życia współczesnej młodzieży, co wiąże się z funkcjonowaniem w aktualnej rzeczywistości społeczno-kulturowej, opartej na konsumpcjonizmie i popkulturze - nurtach promujących ryzyko jako atrakcyjny element egzystencji jednostki. Należy mieć na uwadze również potrzebę świadomości ryzyka. Nie bez znaczenia jest też fakt, iż podejmowanie ryzyka stanowić może swoisty mechanizm obronny przed funkcjonowaniem w rutynowej, przewidywalnej codzienności oraz rzeczywistości standaryzacji, normalizacji i komfortu.

\section{Zakończenie}

Aktualne warunki społeczno-kulturowe oparte na zmianie sprawiają, że koniecznym elementem analizy kondycji społeczeństwa jest analiza refleksji współczesnej młodzieży na temat zaufania oraz ryzyka. Wynika to $\mathrm{z}$ faktu, iż to właśnie ta grupa wiekowa szczególnie bacznie „przygląda się" realiom socjokulturowym, jest ich obserwatorem, ale też aktywnym członkiem wnoszącym świeżość myślenia oraz odwagę do działania. To te cechy konstytutywne okresu adolescencji sprawiają, iż młodzi jako jedni z pierwszych trafnie oceniają zachodzące w systemie społecznym trendy. Zatem opinia współczesnej młodzieży powinna być zauważalna, słyszalna i brana pod uwagę w dyskursie społecznym. Mając to na uwadze, podjęte zostały rozważania na temat kategorii zaufania oraz ryzyka. 
Zaprezentowane zagadnienie stanowić może przestrzeń do podjęcia dalszych analiz, w szczególności implikacji pedagogicznych, które wynikają z istotnej roli zaufania oraz ryzyka w funkcjonowaniu współczesnej młodzieży.

\section{Bibliografia}

Filipiak M. (2009), Młodzież - próba definicji, [w:] G. Kwiatkowska, M. Filipiak (red.), Psychologiczne i społeczne dylematy młodzieży XXI wieku, Lublin.

Fukuyama F. (1997), Zaufanie. Kapitał społeczny a droga do dobrobytu, Warszawa-Wrocław.

Giddens A. (2010), Nowoczesność i tożsamość. „Ja” i społeczeństwo w epoce późnej nowoczesności, Warszawa.

Mamzer H. (2008), Poczucie bezpieczeństwa ontologicznego. Uwarunkowania społeczno-kulturowe, Poznań.

Mamzer H., Zalasiński T. (red.) (2008), Zaufanie a życie społeczne, Poznań.

Melosik Z. (2001), Młodzież. Styl życia i zdrowie, Poznań.

Peret-Drążewska P. (2014), Wspótczesna młodzież postrzegana z perspektywy rówieśników. Studium teoretyczno-emipiryczne, Poznań.

Putnam R. (1995), Demokracja w działaniu: tradycje obywatelskie we współczesnych Włoszech, Kraków.

Sztompka P. (2007), Zaufanie. Fundament społeczeństwa, Kraków.

Zysk T. (1999), Orientacja prorozwojowa, [w:] J. Reykowski, K. Skarżyńska, M. Ziółkowski (red.), Orientacje społeczne jako element mentalności, Poznań. 